\title{
Woman's Representation and Shifting Value in Koplo Dangdut Song
}

\author{
Windaningsih*, Nur Kholis, Herma Retno Prabayanti \\ Communication Science Department, Faculty of Economics and Communication, Bina Nusantara University, \\ Jakarta, Indonesia 11480 \\ *Corresponding author email: windaningsih@binus.ac.id
}

\begin{abstract}
An interesting phenomenon of the rise of Koplo dangdut today are the lyrics that are sung are becoming increasingly varied and get a quick positive response from their fans. Lyrics that tell about infidelity become natural. East Java is in second place in the province with the highest number of widows and high divorce cases due to infidelity. While for Indonesians the case of an affair is something that is considered taboo and there are social sanctions for the perpetrators. Dangdut Koplo ly rics are usually bolder and easier to deliver intentions to the opposite sex. There is a change in the perspective and mindset of women when addressing relationships and feelings of love for the opposite sex. Moreover, it was established that marital ties are no longer seen as something sacred that must be maintained and maintained. In the process of producing and consuming song lyrics, men continue to dominate in certain ways, although they sometimes appear as passive FIGUREs when responding to problems with women. In the socio-cultural context, dangdut koplo has become a form of resistance to various systems that have been suppressed and established by groups of interests. The flexibility of dangdut music to adapt to changing times makes dangdut koplo as music that can adapt in the age of innovation interruption.
\end{abstract}

Keywords: Woman's Representation, Shifting Value, Koplo Dangdut Song

\section{INTRODUCTION}

Dangdut is original Indonesian music that is loved by children with adults. Dangdut music is also synonymous with the taste of music from people from the lower class who are considered less attractive and less stylish. The lyrics of Dangdut became a reflection of the community at that time, mostly with the theme of love and excitement. Weintraub (2012: 12)[1] mentions that dangdut songs raise many social problems that are often avoided by other musical genres. For example about gambling, prostitution, poverty, infertility, homelessness, family destruction and many others. Even William Federick (in Weintroub 2012: 11) [1]mentions dangdut as a prism that is sensitive and useful for viewing Indonesians. Dangdut not only reflects national political and cultural circumstances. Dangdut as a form of economic, political and ideological practice that has helped shape ideas about class, gender and entities in Indonesia.

After the fall of the dangdut, the new order experienced another flood with the rise of dangdut singers with various rocking actions as a characteristic of dangdut music. Such as the rise of Inul Daratista with a rocking shake, Dewi Persik with a rocking saw and many more dangdut shake phenomena that had become a controversy in the 2000s. Dangdut music is popular again, although it exploits the bodies of women as spectacle objects, compared to the development of dangdut itself as entertainment. An informal survey in 2006 of a weekly television program showed that $63 \%$ or 29 of the 43 music programs were devoted to dangdut. While other observations show that dangdut was broadcast on screen for almost ten hours a day (Weintroub 2012: 15), even since 1970, dangdut has enlivened the political scene by being a party in the campaign program. In this case dangdut music is used to mobilize the masses with the aim of promoting candidates in national and regional elections. In addition to dangdut music, a lot is shown in various mass events and entertainment in family events such as weddings, circumcisions, birthdays, reunions or other events. At present dangdut music is entering a new phase with the rise of Koplo dangdut types. Koplo dangdut music has actually become popular since the appearance of Inul Daratista. Stage-to-stage live performance is a medium that quickly makes this type of music popular with the wider community. Dangdut koplo is not synonymous with vulgar wiggling and the various stage attractions of the singer. Dangdut currently plays in a new style where the singer has more interaction with the audience by singing 
together or duets without any variation. Call it Nella Kharisma, and the most phenomenal is Via Valen, who was recently asked by Erik Tohir as the official singer of the Asian games sporting event. Through Valent's performance, dangdut brought music to the mats of international sporting events and automatically provides fresh air for the development of dangdut music[2].

Dangdut is supplied with new packaging and style. Dangdut appears with a taste of language that is known to the public every day. The songs are very quick and easy to follow to sing anytime, anywhere. Call it the songs of Via Vallen and Nella Kharisma, which is now a new idol for most teenagers and also for the people in East Java. One of the songs from Via Vallen, entitled "Sayang", was viewed more than 20 million times and liked more than 300 thousand.Starting with stage music better known as orchestra or electronic performances in various community events in the village, as well as special events in the area, dangdut music is now very popular with most people in the country. An interesting phenomenon of the rise of dangdut with this new model is about the texts that tell about forbidden love or unfaithfulness as if it became something natural. Starting with "Aku Kangen Bojomu" (I miss your husband) "Bojo Ketikung" (husband / wife of Ketikung) "Dirabi Mantan" (married to your ex), and many others. Taking into account the above phenomenon, this writer wants to address the issue of women's representation and shifts in values in the music of Dangdut Koplo

This research focuses on Koplo dangdut as a communication medium capable of transforming social values in society through the song lyrics with a focus on researching how dangdut songs represent women and transform social values into the community.The author wants to see how dangdut koplo transforms different values in society in terms of text packaging, namely lyrics, the production process of text consumption or discourse practices, and how lyrics can transform different values in society in terms of socio-cultural practice.

\section{LITERATURE REVIEW}

This section discusses the text that is the text of the dangdut koplo number selected by linguistic analysis by looking at vocabulary, semantics and sentence structure to see how natural and social representations are in the vision of text producers, how social relationships are represented, through texts in discourse and how identity Text producers are represented and built up in the text[3].

The first four lines of the lyrics use active sentences that show how a woman is portrayed as someone who is just silent, tends to be passive, and forced to accept the situation. The use of the word lilakno, which means clarity, shows that the woman should only remain silent and accept the existing situation. The shift in value seems to be due to the love of woman A for the wife of another woman (B), which subsequently led to the destruction of the woman's feelings, but apparently woman A did not feel guilty and considered what she did as a natural and permissible thing. Sentence Mung tetepno atiku, Selawase aku tresno bojomu (just put my heart, I love your husband) illustrates that women are identical with stubbornness, even if he was wrong. This shows that women are often regarded as irrational beings. The wrong is then seen as something that must be and retain the truth, seen as a stupidity or madness seen in the reff. Women are described as stupid and crazy because they do not realize that when they are misled by men, this is considered a weakness of women, so it becomes obvious when men leave. As can be seen in the following texts What is Apa pancene koe trahe ra iso mikir, Tak kiro pancene awakmu kui sing rodo kenthir, Ora tambah pinter nanging utekmu tambah mlintir. Pantes wae yen bojomu saiki banting setir(You really don't think so, I think you're a little crazy, not getting smarter, but your brain is being twisted. No wonder your husband is waving now). At the end there is a confirmation of the change in values where friends eat friends, that is the trend, even if we cannot accept that it will be beaten or destroyed.

The second issue shows the value shift with a broken friendship because a woman whose husband was 'bent' or imprisoned by her own friend, the B with sweet words or seduction, although very disappointed as implied in the following texts I ra nyongko kowe tego karo konco, Jarene konco kennel, bojoku tok sleding tackle (I didn't think you would have the heart for a friend, he said a good friend, my husband bows to you instead). but wife A did not feel confused, she even gave up her husband for someone else. The shift in values in the form of behavior that is considered greedy because B women who are willing to accept the rest of their own friends, obtained by seizing.

The shift in values in the form of insults done by the A to the B that her husband has captured. Caci Maki uses harsh words to be considered reasonable because the actions of A against B women who are supposed to grab her husband, so it is normal for the A to feel angry and insult the B. Crazy ndang rumatono, crazy ndang untalono Mugo iso happy, sustainable press tuo, Sakjane I nguyu, thinking of your actions, how is it that I have really tormented, took care of my turah (please take care of you, please eat, hopefully happy and sustainable to old I actually laugh, think of your actions How come you are greedy and pick up my leftovers[4] 
While in the third song the value shift is seen in female $\mathrm{A}$, the singer as a subject that still wants to be remembered by his married lover, but will still be missed, as seen in the song Nanging ojo, worried, I am still waiting always. Wait here for the usual place to meet. The value shift can also be seen in the following texts: 'Ora is missing, call iso met. Ora not coro, call iso andum tresno. I let you be slave ra biso divorced, Senadyan wes dense bojo dewe-dewe (no less way, can still meet. No less ways to still be able to share love. Me and you can't get divorced, although you already have a husband and wife This marriage was once considered sacred, but now marriage is no longer a barrier for two people who have their own partners to continue to love each other - this is reinforced by the lyrics of the song that the A -wife confirms who decided to keep waiting for her married lover Something that is taboo or inappropriate for the community in general, because it expects someone else's household to be disadvantaged or destroyed.

The value shift is also seen by the expression that there are still many ways and ways to continue with a few enthusiasts who already have their own life partners by having an affair. The value shift can also be seen in the lyrics of the poem on the cover of the song, namely omp hompimpa alaiyum gambreng, exaggerate the oath selawase slim. ono tekemplek kecemplung segoro, change tuwek call iseh tresno (Hompimpa alaiyum gambreng, sworn forever, together there is a tek dipek dipemplung sea, until the old can still love) that shows how the A remains firmly established until the old is still will love his love lover who has become someone else's husband

\section{RESEARCH METHODS}

The singer identifies herself as a woman who is smart and full of tenderness. This is evident from the very beginning of the lyrics of women identified as a source of trouble and commotion, one of them loving someone else's husband and hurting fellow women. Men are identified as those who remain innocent, although he was initially responsible for the problems that arise, as mentioned in the following texts. Ra should not sing rapalne mantaro comit kamit, Mergo sakjane tingkahe bojomu sing amit amit. (I don't need to chant mantras, because your husband's behavior is actually forbidden God). Men here are also identified as passive and unable to do anything. But it always gets a defense and is justified because the fault lies in the stupidity of women, as confirmed in the following excerpt of the text "Pantes wae yen bojomu simbir control".

In this case, the woman who is in the wrong position, namely the singer, replaces the subject of the song, which is precisely identified as a very active and uncomplicated FIGURE in conveying all the intentions and desires of her heart, and even women do not hesitate to threaten other parties that they do not like, namely the wife.Man and woman's legitimate relationship is identified as something that is not important and outdated, because the trend now is that friends eat friends as mentioned at the end of the lyrics as follows: "Mulo saiki kabeh ceritane erase meant Ra usum is like crito wayang rama lan shinta, Usume saiki kanca yo tego mangan kanco (so now all stories are different, it is no longer the wayang rama shinta story. Now it's the season for friends to eat friends).

In the second issue, women are identified as active FIGUREs fighting for their rights, although in ways that are not laudable, as others scold at telling what they think is right. It also identifies women as emotional, temperament, and hostile, as seen in the following lyrics. Crazy ndang rumatono, crazy ndang untalono, Mugo iso happy, long-term press tuo, Sakjane I am nguyu, mikirke tumikutmu, how come i really aggrand, ngopeni turahanku (you take care right away, you feed you, hopefully i can be happy up to I am laughing while I think of your actions, why are you so greedy to take care of the rest of me) lyrics that this song uses a dictation from the Javanese language of coarse Ngoko with a choice of words that tend to politely missing.

On the other hand, the texts identify women as greedy FIGUREs by still seizing the men of others. Women are identified as a marginalized group because no man likes it if he doesn't grab the other's husband or attracts others in inappropriate ways. While men are identified as a very valuable object that women dispute. Although shown passively, the man is identified here as a very special FIGURE, so that it becomes a struggle and is fought by women in different ways.

Women are identified as stubborn and love to make problems one of them by loving a man who is now married. Here the woman, the singer, identifies herself as a person who faithfully holds her love for her ex-lover, although this should not happen, in this case the woman is identified as the cause of the problem. In addition, women are also considered stubborn because of the steadfast attitude of loving a married loved one.

Women are identified as weak FIGUREs who cannot move or forget the past and choose to be trapped in it. This can be seen in the following text: "Nanging ojo is worried, I am still waiting. Wait here, in the usual place to meet. Ora missing, call ISO. Ora not coro, call iso andum tresno. I lan your slave ra biso divorced, Senadyan wes duwe bojo dewe-dewe. (But don't worry, I'm still waiting. Wait here, at the usual meeting place. You and I can't get divorced, even though we have all our partners) The woman in this song was also identified as someone 
who could not solve the problem and be locked up in a problem she had created herself.

\section{RESULT AND DISCUSSION}

\subsection{Dangdut Koplo in the era of innovation disruption}

The unique style of the singers and the ways in which they perform a song expressively and with appreciation are also still popular. But now the ways to live a song are often different. Dangdut Koplo singer also has a different style from time to time. If we previously found the appreciation of the song in Koplo dangdut, followed by various stage acts with erotic swayes such as those performed by the trio of Maca, Inul Daratista and others, Koplo dangdut is now usually simpler and more relaxed in his carrier, but they give a familiar impression to the macaque. public. Although there are still many dangdut koplo performances that are colored with various erotic and vulgar rocking actions and challenging outfits, natural selection ultimately gives the audience a varied choice. Which is preferred, which is not.

The trends in Dangdut Koplo continue to develop from time to time with different characteristics, including a combination of different genres and arrangements. Here a number of music genres such as pop, regge, ska, keroncong, house music etc. are inserted in songs outside of pure dangdut. Dangdut koplo adapts local music and pop and rock music, so that dangdut music turns into dangdut that can reflect the economic era and unsTABLE social changes (Weintraub, 2013: 83)

Bambang Jatmiko said that the presence of Via Valen and Nella Kharisma has improved the image of dangdut music in order to improve even those who are not yet familiar with Koplo dangdut. The number of viewers of these two singers on YouTube can even surpass popular pop singers in the country. Dangdut Koplo proved to succeed in the music industry of the country. This is inextricably linked to the flexibility of dangdut itself, which can be very easily adapted to different music genres and existing technology. In line with existing trends, dangdut has been able to present better and to conceal the shortcomings of the previous types of dangdut. Through traps and Nela Kharisma, dangdut brings Koplo music with a very relaxed, non-vulgar and simple but fashionable make-up like a Korean artist. This then becomes one of its own attractions for millennials to more easily accept dangdut koplo as an alternative entertainment music that they can enjoy.

Dangdut koplo is no longer synonymous with the appearance of vulgar vulgarity. But dangdut has been able to look more elegant and modern in the age of disruption innovation. By bringing koplo dangdut and its elegant appearance, Via Fall and Nela
Kharisma can change the existence of dangdut artists who have been there before. Moreover, these singers are free of oblique gossip that are usually known by celebrities. Dangdut fans who have been bored and bored with controversial artists with various slanting gossip that they usually know are now relieved by the expectations of Nella and Via. For consumers in the entertainment world who are still considering Eastern values, this is certainly an added value. Jatmiko also emphasized that Koplo dangdut could take advantage of the existing market via YouTube and even created a new market with the inclusion of a middle class whose music tastes were unclear, which subsequently appeared in the list of Koplo dangdut fans.

The presence of dangdut music with such a display gives a more positive picture compared to the previous era. In addition to the diversity of the stage acts, the lyrics of the song dangdut koplo are also very diverse. Weintraub (2012: 152-153) writes that the lyrics of dangdut have their own world that is different from the world of jogging music. Dangdut music circulates through recordings on radio and television. When listening to dangdut music, people are not limited to dancing, but sing along with the lyrics of the song when they travel, relax or hang out and in various other activities. Dangdut lyrics are also a way to express something to his fans, accompanied by certain styles or infections upon delivery.

The love themes remain an interesting theme in a song. With singers or singers dominated by women, lyrics from dangdut sound more intriguing with the different stories being told. It also contains a forbidden love story that is not actually a new menu in song lyrics, but how this forbidden love story is shown now makes us think about the position of women. In the 80s-90s era we found many forbidden love stories, such as in the song "Sugar" sung by Elvi Sukesi, Smile Brings Wounds and Surrender sung by Meggi Z. We can see how forbidden love or perhaps unfaithfulness becomes described. In the past, illegal affair or forbidden love appeared in the song as a sad story that was experienced by the singer who fell victim to her unfaithful partner. How there is a fragment in the left number of the text "how could you ... how could you ... how could you be to me" that confirms that the singer's partner is very cruel. For songs sung by women, it is clearly illustrated how a man is often the cause of problems with all the bad qualities he has, such as gambling, drinking and playing with women. This causes women to suffer and fall victim to their bad attitude.

\subsection{Dangdut Koplo and the daily life of the East Java people}

Enjoying dangdut songs has become a daily part of the lives of the people of the country. Music is a 
universal language that is able to communicate different messages precisely to its fans. Likewise with dangdut music. From the beginning, enjoying music at various activities has become part of our community life, whether during weddings, parties, birthdays, relaxing times, on the road, or while gathering with friends or hanging out in different places.

Many people who were initially unfamiliar with Koplo dangdut music got to know Koplo-dangdut songs and even remembered them, because these songs were often played in different places in different situations. Call it television shows on the intercity bus. Very often the bus crew plays dangdut koplo songs to entertain their passengers so they don't get bored. Perhaps for those who don't like Koplo dangdut numbers, they will tend to ignore it and choose to sleep or play a device. But for the connoisseurs of this music, the journey is accompanied by the music of dangdut koplo more fun and can reduce boredom and boredom because of the distance that has to be traveled. It is not uncommon for these moments that people love Kopang dangdut songs.

Apart from the many illegal DVDs and CDs that are sold cheaply, such as hotcakes and also the development of digital media that make it easier for music fans, including the fan of dangdut koplo, it is easier to access different songs that he digitally and likes it online. From the beginning, Koplo dangdut has become a popular music and it grows from phase to phase of the Malaysian orchestra. If the era of the new order dangdut largely dominates the campaign phase as a means to entertain campaign participants, dangdut koplo is currently at a more specific stage. Dangdut Koplo, together with the Malaysian orchestra group, usually appeared at a public celebration and party invitation. What the average invited was that most people were not just politicians like before. Even Koplo dangdut can be an indicator of the economic community. People who invite the Malaysian orchestra dangdut koplo-podium are usually regarded as a reasonably well-established economic level or in other words as rich or capable people, because in principle inviting the Malaysian orchestra group does not require a small amount of money. It all depends on how well the Malaysian orchestra has been invited with the singer who is the guest star. The more famous the artist and the orchestra with its accompanist will automatically pay more expensive fees.

Dancing together becomes a pleasant momentum for connoisseurs of dangdut koplo music. Although the singers on stage did not show the lively shaking, the audience could still dance cool. Even now we can easily find a jogging community that consists of a group of young people dancing to the rhythm of the song being sung. This community usually dances with unique and uniform movements that follow the rhythm of music, livening up the atmosphere to enjoy the dangdut koplo music.

Part of the audience of dangdut koplo are young mothers with different characters, there are people who prefer to enjoy the song while only doing activities but are not interested in watching it directly. There are also young mothers who really want to see the dangdut koplo program, not even hesitate to jog along. For those who are important, the music is cool for jogging and to be happy, the question of the text does not occur to me, although it sometimes sounds strange that they only use it as a joke to reduce fatigue because of the various problems that they have in life. While young people usually make the dangdut koplo music event a place to come together and have fun with friends. It is not uncommon for them to be involved in commotion and to fight because of too fast jogging, causing the public to create friction that has led to commotion. In addition, it is sometimes also found that young people who get into a drunk state after drinking alcohol often cause a scene. Dangdut Koplo, often underestimated as entertainment for the grassroots group, is able to stir up the passion and love of his fans.

\subsection{Women as Objects in the Mat Dangdut Koplo}

The Dangdut scene, which often presents women as objects of sexuality by merely exploring the bodies of women, has now been replaced by a more polite and elegant look. There are, however, many dangdut lyrics that we find that contain a variety of feminine traits that are often described. The ability of women to appear courageous and full of self-confidence and is not always seen as positive when combined with various forbidden love song lyrics. Women are still the same, that is, beings who are less rational, often emotional, and also not good at controlling themselves.

Women who are now better shown on the entertainment stage still have a view that is still not much different than before. Women as mere sex objects only serve to satisfy men's desires. The women in prison were no longer passive, but were raised instead by the change in women's values. Where women with a positive image are gentle gentlemen. Women appear here with an attitude that tends to be active, but in a negative sense. Active for things that do not conform to the values and norms that exist in society. However, this has become something that is no longer a problem and can even be ignored. Seen from the fact that the lyrics of the song that was deviated from were no longer something that was ignored by the audience that is the audience of dangdut music. 
Referring to the institutional aspect, since the 1970s, dangdut has become a special attraction for the country's political scene to attract massive interest in campaigning events. At the time, dangdut music fans occupied the lower layers of the economic, political structure and were described as small people, ordinary people, marginal people. In the 1990s, dangdut was successfully attracted to national discourse because of its increasing popularity after it was produced by commercial private television.

In the dangdut music performance, most women who appear on stage appear as an economic factor as a motivation to join the dangdut singer with various risks. In the dangdut phase, women are still harassed in various situations, both when they appear on and off stage. As a singer more empowered as an economic actor by this dangdut music, but her role here is still regarded as mere objects.

\section{CONCLUTION}

The lyrics of the dangdut-koplo song that is currently being performed by female singers are usually bolder and easier in transferring intentions to the opposite sex. There is a change in the way of thinking and the mentality of women in addressing the relationships and feelings of love for the opposite sex. It was also established that the marriage bond was no longer seen as something sacred that must be maintained and maintained. But the bond of marriage is only seen as something that is no longer popular because it has been replaced by the popularity of infidelity, towards other couples as well as the closest couple of people as with a partner of his own friends.

Patriarchal culture is still rooted in a society that ensures that men remain in a position that always benefits. While producing and consuming song lyrics, men continue to dominate in certain ways, although they sometimes appear as passive characters when responding to problems with intimacy. In the socio-cultural context, dangdut koplo has become a form of resistance to various systems that have been suppressed and established by groups that have an interest in it. The flexibility of dangdut music when adapting to developments makes Koplo dangdut as music that can adapt to the age of innovation interruption.

\section{REFERENCES}

[1] A. N. 2012. Weintraub, Dangdut Musik, Identitas, dan Budaya Indonesia. Jakarta: Gramedia. .

[2] Eriyanto. 2009., Analisis Wacana: Pengantar Analisis Teks Media. Yogyakarta: LKiS. .

[3] N. 2003. Fairclough, Language and Power: Relasi Bahasa, Kekuasaan dan Ideologi. Malang: Boyan Publishing. .

[4] H. 2005. Hardt, Critical Communication Studies: Sebuah Pengantar Komprehensif Sejarah Perjumpaan Tradisi Kritis Eropa dan Tradisi Pragmatis Amerika. Yogyakarta: Jalasutra. .

[5] A. 2002. Sobur, Analisis Teks Media. Bandung: Remaja Rosdakarya. . 